\title{
Detection Of Escherichia Coli, An Indicator Of Feacal Contamination, In Drinking Water Sources In Amassoma, Niger Delta Of Nigeria.
}

\author{
E.N. Ogamba* and Tobia, P.S \\ Department of Biological Sciences, Niger Delta University, Wilberforce Island, P.M.B. 071, Yenagoa, Bayelsa \\ State, Nigeria.
}

\begin{abstract}
The detection of Escherichia coli as an indicator of faucal contamination in drinking water sources in Amassoma town, a host Community of the Niger Delta University, Bayelsa State in the Niger Delta of Nigeria, was carried out to determine their suitability for drinking. Result obtained showed mean total coliform bacterial counts of $2.05 \times 10^{3} \mathrm{cfu} / \mathrm{ml}$ for borehole water, $1.25 \times 10^{3} \mathrm{cfu} / \mathrm{ml}$ for well water and $1.0 \times 10^{3}$ for pipe borne water. The mean count of faecal coliform was $2.1 \times 10^{3} \mathrm{cfu} / \mathrm{ml}$ for borehole water, $4.5 \times 10 \mathrm{cfu} / \mathrm{ml}$ for well water and 1.0x10 cfu/ml for pipe borne water. The faecal coliform identified was Escherichia coli. Sources of contamination were found to be septic tanks, waste dump sites and periodic flooding of the area, being a typical wetland environment. It was concluded that water from the different sources studied in Amassoma did not meet the world health Organization (WHO) standard for drinking water. This study has therefore shown the need for continuous monitoring of our water supply systems.
\end{abstract}

Key words: Escherichia coli, fecal contamination, drinking water, Niger Delta.

\section{Introduction}

Water is a clear liquid without taste and smell when pure, and is one of the most abundant natural resources which cover about 70\% of the earth's surface. It is the medium of life's processes (Penman, 1976). About $70 \%$ of human weight is made up of water and many biochemical functions in the body depend on it.

One of the most important uses of water is for drinking. Water can be sourced from surface or underground sources for individual dwelling supply or municipal water supply.

In most cities, water is treated before it is supplied to consumers. The methods used in municipal water purification plants to produce portable water include sedimentation, filtration and chlorination. Sedimentation occurs in long or large reservoirs where the water remains for a holding period. Large particulate matter settles at the buttom. Sedimentation is enhanced by the addition of alum (Aluminum sulphate) which produces a sticky precipitate at the surface. Many micro-organisms and finely suspended particulate materials are removed as these particulates descend through the water into settling beds. The water is then chlorinated to kill the remaining micro-organisms and to also ensure its portability.

The world Health Organization (WHO), 1984 standards for drinking water stipulates that water for dinking should not contain organisms that are pathogenic to man; water should not contain toxic substances; water should not be turbid, reasonably soft, non-corrosive with low concentration of iron and manganese. It was also reported that water for human consumption must be free from all objectionable odour, turbidity, taste, enteric pathogenic bacteria, unwanted dissolved chemicals and other aesthetically offensive objects (Okafor, 1985; Dawson and Satory, 2000).

Water gotten from boreholes and tap in its natural state may not be contaminated but when in contact with pathogens or microbial agents will definitely become contaminated and unfit for domestic uses (McCane and Kandel, 1986; Eja, 2002). The most common source of pollution of water is when water is contaminated with faeces from infected persons, and a single outbreak of water-borne disease may affect thousands of people.

Water sources, when contaminated with micro-organisms cause a number of infections of intestinal tract such as paratyphoid fever, cholera, dysentery, shigellosis and amoebiasis. These water-borne diseases are typically caused by enteric pathogens which begin by faecal-oral route (WHO, 2004). The number of organisms required to cause disease in an individual depends on a variety of factors, including the particular organism and its virulence, and the health of the individual.

More than half of the world's population live in villages in rural areas and most of those without access to safe drinking water supply or basic sanitation are rural dwellers (Howard et.al., 2002). Globally, 1.1 billion people rely on drinking water sources from lakes, rivers, and open wells. The majority of these are in Asia (20\%) and sub-Saharan Africa (42\%). Furthermore, 2.4 billion people lack adequate sanitation worldwide (WHO/UNICEF, 2000; WHO/UNICEF JMP, 2004). 
In safeguarding public water supplies, public health authorities and engineers rely on information obtained from the results of frequent bacteriological tests. In bacteriological water analysis, the recovery of conventional indicator bacteria such as the coliform $\underline{\text { E.coli }}$, feacal entherococci and anaerobic endospore forming Clostridium perfringens, provides a reliable means of assessing the extent of pollution as their presence is indicative of a possible presence of enteric pathogenic bacteria in such water (Itah etal; 1996).

The recognition that microbial infection can be water induced has led to routine examination to ensure that water intended for human consumption is free from sewage pollution. It is impracticable to monitor drinking water for every possible microbial pathogen that might occur during examination (Itah et.al; 1996). A more logical approach is the detection of organisms normally present in the feaces of animals and man as an indicator of feacal pollution. The presence of indicator organisms suggest the presence of other pathogens in water. The absence of indicator organisms may probably indicate the absence of other pathogens. Since water is a very important reservoir of human pathogens, drinking water supplies liable to contamination with sewage or excreted matter may cause outbreaks of intestinal infections (Cruickshank et.al; 1975).

The family Enterobacteriaceae are ubiquitous organisms that are found world wide in soil water, vegetation and are also normal intestinal flora of most animals including humans. Members of the family include Shigella and Salmonella, and are associated with diseases when isolated from humans, whereas others like E. coli and Klebsiella are members of the normal commensal flora that can cause opportunistic infections. Coliform bacteria are all Gram-negative, non-spore forming, rod shaped bacteria, capable of fermenting lactose and also capable of growing aerobically, with production of acid and gas at $35^{\circ} \mathrm{c}$ in less than 45 hours. Coliform bacteria will not likely cause illness, but their presence in drinking water indicates the presence of disease causing organisms such as Salmonella.

There are two different groups of coliform bacteria namely: Total coliform bacteria and feacal coliform bacteria; based on incubation temperatures, with each of them having different levels of risk. Eschericha coli is a sub-group of the feacal coliform. Most Eschericha coli are harmless and are found in great quantities in the intestine of warm-blooded animals and humans. Their presence in a drinking water sample indicates recent feacal contamination.

The aim of this study therefore, is to identify Eschericha coli as an indicator of feacal contamination in drinking water and thus, determine the suitability of water from different supply sources in Amassoma for drinking. The study will also provide data that may be useful for the effective management of drinking water supply systems in Amassoma, a typical wetland environment.

\section{Sample Collection}

\section{Material And Methods}

Samples were collected from different wells and boreholes located in Amassoma town, while pipe borne water was collected from a tap in the Niger Delta University Campus, and another from a public tap in Amassoma. All samples were aseptically collected into sterile containers and transported to the laboratory for analysis. Two sets of samples were collected at two weeks interval, and labeled sample set 1 and sample set 2 respectively. For the pipe born and borehole water, the taps were left to run for one minute in order to free the pipes of any stagnant water. Each sample container was filled to capacity, for well water, the sterile containers were plunged into the well below the water surface and the containers were filled.

\section{Identification of Micro-Organisms:}

Each of the samples was serially diluted by pipetting and transferring Iml of sample into $9 \mathrm{mls}$ of sterile water in the test tube down the dilution gradient up to $10^{4}$ for all three samples. $14 \mathrm{~g}$ of nutrient agar was mixed with $250 \mathrm{mls}$ of sterile water in a flask, the growth media was sterilized by autoclaving for 15 minutes at 15 pounds per square inch pressure at temperature of $121^{\circ} \mathrm{c}$. The sterile molten media was poured into plates containing decimal dilution (aliquot) of each sample and allowed to set and incubated for 24 hours at $37^{\circ} \mathrm{c}$. Yellow colonies that developed after incubation were counted and reported as total coliform.

With the same water samples, multiple tube fermentation was set up for borehole water, pipe born water and well water according to the standard methods outlined in APHA (1998) guidelines. After which the test tubes were observed for gas production. Also, confirmatory test for the identification of_Eschericha coli was done following the standard methods described in APHA (1998) guidelines. Colonies that developed with greenish sheen were counted and reported as Eschericha coli (Feacal Coliform). This was done for all three samples.

Generally, the organisms were identified according to their colonial morphology. The grams reaction test was however, carried out according to the method specified by Cowan (1985). 


\section{Results}

The temperature readings of the water samples from the different water supply sources in Amassoma are presented in table I, while those of Eschericha coli identification and characterization are presented in tables 2 and 3. The colony forming unit (cfu) per $\mathrm{ml}$ of the original culture is gotten by multiplying the number of colonies on the plate by the dilution factor.

It was observed that well water had the highest level of feacal coliform contamination for both the first set (SS1) and second set (SS2) of samples, $4.0 \times 10^{3} \mathrm{cfu} / \mathrm{ml}$ and $5.0 \times 10^{3} \mathrm{cfu} / \mathrm{ml}$, respectively. This was followed by borehole water which had values of $2.0 \times 10^{3} \mathrm{cfu} / \mathrm{ml}$ and $2.2 \times 10^{3} \mathrm{cfu} / \mathrm{ml}$ for the first and second set of water samples respectively. Pipe borne water had the least level of feacal coliform contamination of $1.0 \mathrm{x}$ $10^{3} \mathrm{cfu} / \mathrm{ml}$ for both the first and second set of water samples.

TABLE 1:Temperature of water samples from different supply sources in Amassoma

\begin{tabular}{|l|l|l|}
\hline Sample type & Temperature of sample set 1 & Temperature of sample set 2 \\
\hline Pipe borne Water & $31.4^{\circ} \mathrm{c}$ & $31.3^{\circ} \mathrm{c}$ \\
\hline Well Water & $31.0^{\circ} \mathrm{c}$ & $31.2^{\circ} \mathrm{c}$ \\
\hline Borehole Water & $31.3^{\circ} \mathrm{c}$ & $31.3^{\circ} \mathrm{c}$ \\
\hline
\end{tabular}

TABLE 2:Cell count for total coliform and feacal coliform for the different water samples (SS1)

\begin{tabular}{|l|l|l|}
\hline Sample type & Total Coliform & Feacal Coliform \\
\hline Pipe borne Water & $2.0 \times 10^{3} \mathrm{cfu} / \mathrm{ml}$ & $1.0 \times 10^{3} \mathrm{cfu} / \mathrm{ml}$ \\
\hline Well Water & $1.0 \times 10^{4} \mathrm{cfu} / \mathrm{ml}$ & $4.0 \times 10^{3} \mathrm{cfu} / \mathrm{ml}$ \\
\hline Borehole Water & $1.0 \times 10^{3} \mathrm{cfu} / \mathrm{ml}$ & $2.0 \times 10^{3} \mathrm{cfu} / \mathrm{ml}$ \\
\hline
\end{tabular}

TABLE 3:Cell count for total coliform and feacal coliform for the different water samples (SS2)

\begin{tabular}{|l|l|l|}
\hline Sample type & Total Coliform & Feacal Coliform \\
\hline Pipe borne Water & $2.1 \times 10^{3} \mathrm{cfu} / \mathrm{ml}$ & $1.0 \times 10^{3} \mathrm{cfu} / \mathrm{ml}$ \\
\hline Well Water & $1.5 \times 10^{4} \mathrm{cfu} / \mathrm{ml}$ & $5.0 \times 10^{3} \mathrm{cfu} / \mathrm{ml}$ \\
\hline Borehole Water & $1.8 \times 10^{3} \mathrm{cfu} / \mathrm{ml}$ & $2.2 \times 10^{3} \mathrm{cfu} / \mathrm{ml}$ \\
\hline
\end{tabular}

\section{Discussion}

Microbial analysis of drinking water samples from the pipe born water, well water and borehole water supply systems in Amassoma town revealed the presence of Eschericha coli, a bacterial indicator of feacal pollution.

The isolation of Eschericha coli from well water is an indication of recent feacal contamination. The well water had the highest level of feacal contamination, $4.0 \times 10^{3} \mathrm{cfu} / \mathrm{ml}$ and $5.0 \times 10^{3} \mathrm{cfu} / \mathrm{ml}$ for the SS1 and SS2 samples respectively. This could be due to the location of these wells close to septic tanks and waste dump sites. Most of the wells do not have lids. Also, during periods high water level which peaks during the months of August through October in the Niger Delta, most of the wells are submerged by flood.

Borehole water is underground water and underground water is known to be bacteria free (Eja, 2002). However, the SS1 borehole water samples had $2.0 \times 10^{3} \mathrm{cfu} / \mathrm{ml}$, while the SS2/Water samples had $2.2 \times 10^{3}$ $\mathrm{cfu} / \mathrm{ml}$. The possible sources of contamination were found to include septic tanks and cracks in running pipes among others. These contaminants could percolate through porous soil and eventually reach the water table. Sometimes borehole water are supplied direct from the pumping stations without treatment.

Pipe borne water had the least feacal coliform count of $1.0 \times 10^{3} \mathrm{cfu} / \mathrm{ml}$ for both sets of samples. The reason may be because the pipe borne water comes from the water treatment plants owned by the state government. The degree of portability depends on the treatment given. In water treatment, impurities and other particles in the water are removed, and the chlorine is added in the form of sodium hypochlorite to kill microbial population.

Amassoma Community is a typical wetland environment with the majority of the inhabitant living in clusters along the banks of the river nun that passes through the community. Over $40 \%$ of the inhabitants live in batcher houses with pier toilet system being a common feature of the riverine settlement. During 2012, flooding season that started in Octoberl, more than $90 \%$ of the land area including the Niger Delta University Campus, was submerged by flood. Also, over $80 \%$ of the inhabitants were displaced from their residences by flood. All the wells and most borehole heads were equally submerged. This kind of situation corresponds to the conditions described by Howard et.al. (2002) and WHO/UNICEF JMP, (2004), that increase the chances of feacal contamination of water sources.

In all, the presence of Eschericha coli in all water samples from well water, borehole water and pipebore water systems shows that the drinking water supply systems in Amassoma are contaminated by feacal 
matter, and therefore not portable (WHO, 2002). Also, the presence of Eschericha coli, an indicator organism, suggests the presence of other pathogens such as Salmonella typhi, Vibrio cholera, Entamoeba histolytica etc. This obviously, posses great danger to the lives of the people in Amassoma Community (WHO, 2004).

\section{References}

[1]. American Public Health Association (ALPHA) (1998). Standard Methods for the Evaluation of Water and Waste Water. 20 ${ }^{\text {th }}$ Ed. Washington, D. C. American Public Health.

[2]. Cruickshank, R., Dugud, J. P. Marmian, B. P. \& Swan, R.H.A. (1975). Medical Microbiology, (The practice of Medical Microbiology) Churchill Livingstone Edinburgh Vol. 11. $12^{\text {th }}$ Edition.

[3]. Cowan, S. T. (1985). Cowan and Steel Manual for identification of Medical bacteria $4^{\text {th }}$ Edition London: Cambridge University Press 1985.

[4]. Dawson, D. J. \& Satory , D. P. (2002). Microbiological Safety of Water. British Medical Bulletin 56 (1):74-83.

[5]. Eja, M. E. (2002. Water Pollution and Sanitation fro developing Countries. Department of Microbiology, University of Calabar, Publishing (2001) Calabar, Nigeria.

[6]. Howard, G., Goldstein, G., Morgan, J., Pruss, A. \& Shaw, R. J. (2002). Healthy Villages; A guide for communities and community Health workers WEAC Loughborough University ISBN 921545534.

[7]. Itah, A. Y. Etukudo, S.M. \& Akpan, E. J. (1996). Bacteriological and Chemical Analysis of some rural Water supplies in Calabar, Nigeria. West African Journal of Biological and Applied Chemistry 41:1-10.

[8]. McCane, L. \& Kandel, J. (1986). Microbiology Essentials and Application. McGraw Hill Books New York International; Ed. Pp 681-686.

[9]. Okafor, N. (1985). Aquatic Microbiology. Fourth dimension Publishing Company Limited Enugu, Nigeria PP. 117-127.

[10]. Penman, H. L. (1976). The Biosphere: The Water Cycle; A Scientist American Book. W. H. Freeman and Co. San Francisco, PP. 40-54

[11]. World Health Organization (1984). Guidelines for Drinking Water Quality, Geneva, pp.7-52.

[12]. World Health Organization/United Nations International Children's Education Fund (2000). Global Water Supply and Sanitation Assessment Report. Geneva, World Health Organization ISBN 944150201.

[13]. World Health Organization (2002). Managing Water in the Home; Accelerated Health Gains from improved Water Supply; Geneva; World Health Organization Document No. WHO/SDE/WDE/WSH/02.

[14]. World Health Organization (2004). World Health Report. Shaping our future. World Health Organization ISBN 9241562439

[15]. World Health Organization/United Nations International Children's Education Fund (2004). Meeting the MDG Drinking Water and sanitation. A midterm Assessment of Progress, Geneva. WHO/UNICEF, ISBN 92421562781 